\title{
Synthesis of an orthogonally protected polyhydroxylated cyclopentene
} from L-sorbose.

Jones, Leigh; Lo Re, Daniel; Giralt, Ernest; Murphy, Paul

\section{Chemistry - An Asian Journal}

DOI:

10.1002/asia.201600736

Published: 20/07/2016

Peer reviewed version

Cyswllt i'r cyhoeddiad / Link to publication

Dyfyniad o'r fersiwn a gyhoeddwyd / Citation for published version (APA):

Jones, L., Lo Re, D., Giralt, E., \& Murphy, P. (2016). Synthesis of an orthogonally protected polyhydroxylated cyclopentene from L-sorbose. Chemistry - An Asian Journal , 11(14), 20352040. https://doi.org/10.1002/asia.201600736

\footnotetext{
Hawliau Cyffredinol / General rights

Copyright and moral rights for the publications made accessible in the public portal are retained by the authors and/or other copyright owners and it is a condition of accessing publications that users recognise and abide by the legal requirements associated with these rights.

- Users may download and print one copy of any publication from the public portal for the purpose of private study or research.

- You may not further distribute the material or use it for any profit-making activity or commercial gain

- You may freely distribute the URL identifying the publication in the public portal ?
}

Take down policy

If you believe that this document breaches copyright please contact us providing details, and we will remove access to the work immediately and investigate your claim. 


\title{
Synthesis of an orthogonally protected polyhydroxylated cyclopentene from L-sorbose
}

\author{
Daniele Lo Re ${ }^{a \star}$, Leigh Jones ${ }^{\mathrm{a}}$, Ernest Giralt ${ }^{\mathrm{b}, \mathrm{c}}$ and Paul Murphy ${ }^{\mathrm{a} *}$ \\ Dedicated to $\mathrm{M}^{\mathrm{a}}$ Teresa Plaza López-Espinosa on the occasion of her retirement ((optional))
}

\begin{abstract}
The use of L-sorbose in synthesis of functionalized cyclopentene derivatives was accomplished. These cyclopentene derivatives are related to those found in naturally occurring jatrophone frameworks and in other bioactive compounds. The formation of allyl $\alpha$-L-sorbopyranoside was a key synthetic step. Regioselective introduction of protecting groups was followed by the hydrolysis of the allyl glycoside to furnish a fully protected acyclic L-sorbose derivative. This acyclic intermediate was subsequently used to give an orthogonally protected polyhydroxylated cyclopentene, which has potential in further bioactive compound synthesis. The protected cyclopentene itself showed a clear cytotoxic activity when tested against a panel of human cancer cell lines (HT29, LS174T, SW620, A549, HeLa cells).
\end{abstract}

The occurrence of resistance to anticancer agents is a major obstacle for successful cancer chemotherapy. The emergence of resistance to anticancer drugs, in particular multidrug resistance (MDR) has made many of the available anticancer drugs

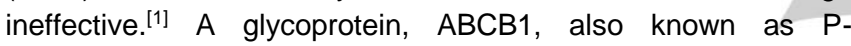
glycoprotein, is a membrane protein member of the $A B C$ transporters superfamily. These membrane-embedded transport proteins decrease the intracellular drug accumulation, by and ATP-dependent efflux. This reduces the cytotoxicity of the anticancer agent and enables the tumor cells to survive. Jatrophanes, such as 1-3, are natural compounds extracted from plants of the genus of Euphorbia. A broad range of biological properties have been reported for constituents of the plant extract. ${ }^{[2]}$ In particular, jatrophanes are potent and specific $P$ glycoprotein modulators. ${ }^{[3]}$ In addition, a variety of other biological activities have been reported: inhibitory activity on the mammalian mitochondrial respiratory chain, ${ }^{[4]}$ antiviral activity, ${ }^{[5]}$ microtubole interaction, ${ }^{[6]}$ antiplasmodial activity, ${ }^{[7]}$ cytotoxicity against various human cancer cell lines ${ }^{[8]}$.

It has been reported that modifications of the cyclopentene (ring A) of the jatrophane framework, resulted in increased biological

[a] Dr. D. Lo Re, Prof. P.V. Murphy, Dr. L. Jones School of Chemistry

National University of Ireland, Galway

University Road, Galway, Ireland

E-mail: daniele.lore@irbbarcelona.org

E-Mail: paul.v.murphy@nuigalway.ie

[b] Prof. Ernest Giralt

Institute for Research in Biomedicine (IRB Barcelona), The

Barcelona Institute of Science and Technology

C/Baldiri Reixac 10, Barcelona, E-08028, Spain

[c] Prof. Ernest Giralt

Department of Organic Chemistry

University of Barcelona

Marti i Franques 1-11, Barcelona, E-08028, Spain

Supporting information for this article is given via a link at the activity (figure 1). ${ }^{[9]}$ For instance, Hierseman and co-workers ${ }^{[9]}$ demonstrated that introduction of aromatic lipophilic substituent at C-3 enhanced the ABCB1 inhibitory activity (figure 1). They also show that there is a correlation between overall lipophilicity and ABCB1 inhibition. ${ }^{[9]}$

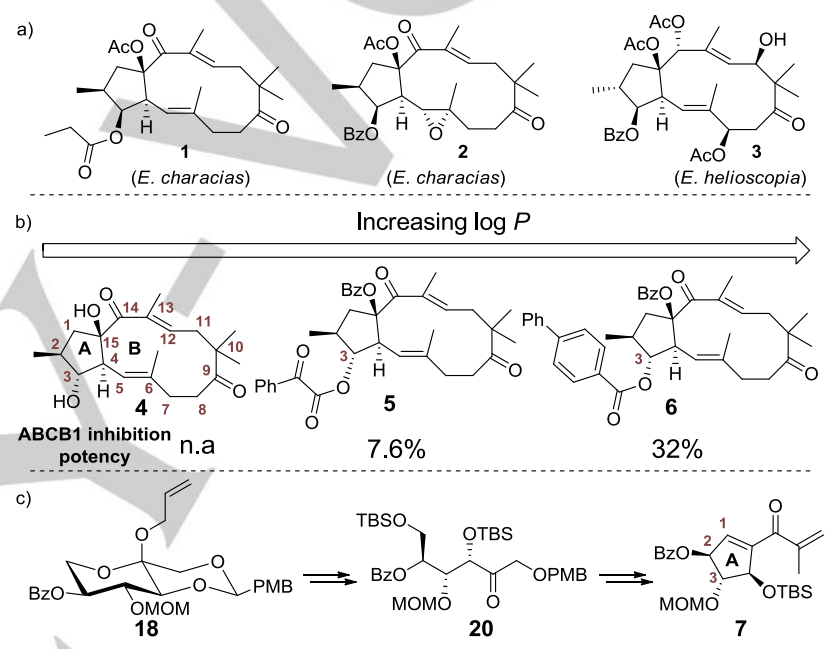

Figure 1. a) Structure of selected jatrophane natural products; b) synthetic jatrophane analogues and their activity against $A B C B 1 ; c)$ orthogonally protected pyranose 18 and open-chain sorbose derivatives 20 and the orthogonal protected cyclopentene 7 prepared herein.

Nevertheless, the potential to prepare cyclopentene derivatives related to those found in $\mathbf{4}$ and which would ultimately be used to give new jatrophone analogues has formed the motivation for the work described herein. We envisaged that the preparation of orthogonally protected polyhydroxylated cyclopentanol $\mathbf{7}$, similar to the ring $A$ of the jatrophane framework, is relevant to the preparation of jatrophane analogues with increased biological activity and for structure-activity relationships. In addition, advanced intermediate $\mathbf{7}$ can be also used for the preparation of biologically active cyclopentitols or cyclopentenols. These are polyhydroxylated cyclopentanes, ${ }^{[10]}$ that display a plethora of biological activity such as found for the glycosidase inhibitors trehazolin and mannostatin, ${ }^{[10 a]}{ }^{[11]}$ the anticancer and antibiotic pactamycin ${ }^{[12]}$ and the insecticide ryanodine. ${ }^{[13]}$ In addition, cyclopentenols, are also important because of their presence in numerous biologically active targets such as the antibiotic pentenomycin, ${ }^{[14]}$ the anti-inflammatory monotropein, ${ }^{[15]}$ and the anticancer compound (-)-neplanocin A. ${ }^{[16]}$

It was envisaged that the construction of the polyhydroxylated cyclopentene could be achieved through a ring-closing metathesis ${ }^{[10 c, 17]}(\mathrm{RCM})$ reaction of fully protected diene such as that in 11. Since RCM could be challenging in such a densely 
substituted diene, ${ }^{[18]}$ we first prepared $\mathbf{1 1}$ in order to validate the synthetic strategy.

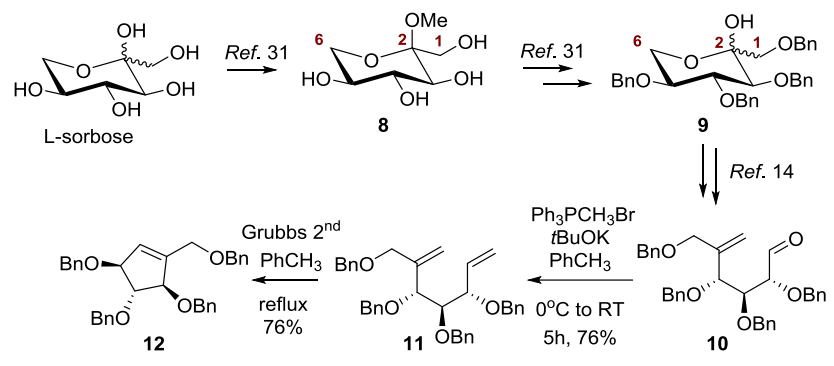

Scheme 1. Preliminary validation of the synthetic strategy from L-sorbose: synthesis of per-O-benzylated cyclopentane 12.

Compound 9 has been prepared from L-sorbose previously. ${ }^{[19]}$ However, in our hands, attempts to simultaneously install olefin at C6 and C2 through directly oxidation of 9 followed by a concomitant double Wittig reaction were unsuccessful. Oxidation of the latent alcohol of 9 under Swern conditions followed by Wittig reaction only gave a complex mixture while treatment of 9 with the Dess-Martin reagent gave no reaction. For these reasons, aldehyde 10 was first prepared as reported ${ }^{[19]}$ and then treated with $\mathrm{Ph}_{3} \mathrm{PCH}_{3} \mathrm{Br}$ and $t \mathrm{BuOK}$ to give the desired diene 11. The $\mathrm{RCM}$ of $\mathbf{1 1}$ using the Grubbs $2^{\text {nd }}$ generation catalyst at room temperature only gave only recovered starting material. However, when the RCM was carried out by heating in refluxing toluene, the polyhydroxylated cyclopentene $\mathbf{1 2}$ was isolated in good yield (76\%, Scheme 1).

With these encouraging observations in hand, it was next decided to exploit this strategy for the preparation of an orthogonally protected L-sorbose derivative. Chemical manipulation of $\mathrm{L}$ sorbose is often carried out via its methyl L-sorbopyranoside ${ }^{[19]}$ or its 2,3:4:6-di-O-isopropyliden- $\alpha$-L-sorbofuranose. ${ }^{[18,20]}$ However, these synthetic approaches suffer drawbacks. In fact, hydrolysis of the dioxolane ring (for the L-sorbofuranose) or hydrolysis of the methyl glycoside (for the L-sorbopyranoside) requires strong acidic conditions, which are not compatible with several functional or protecting groups. On other hand, the allyl group ${ }^{[21]}$ can be removed in the presence of different protecting groups ${ }^{[22]}$ under relatively mild conditions. ${ }^{[23]}$ Since the synthesis of the Lsorbopyranoside 8 is achieved using $\mathrm{MeOH}$ in the presence of acetyl chloride $(\mathrm{AcCl})$, we hypothesized that similar conditions could be used for the preparation of the allyl glycoside 13. In fact, treatment of L-sorbose with allyl alcohol and $\mathrm{AcCl}$ gave 13 in 64\% yield. However, at this stage we could not establish the stereochemical configuration of 13. However, ${ }^{1} \mathrm{H}-\mathrm{NMR}$ analysis suggested the formation of the pyranose ring $\left(J_{3,4}=9.5 \mathrm{~Hz} ; J_{5,6}=\right.$ $10.4 ; J_{4,5}=8.7 ; J_{5,6^{\prime}}=5.4$ ) had occurred. Fortunately, regioselective protection of hydroxyl groups at C-1 and C-3 using anisaldehyde dimethyl acetal in presence of camphorsulphonic acid gave $\mathbf{1 4}$ in good yield (scheme 2) which crystallized from a mixture of $\mathrm{MeOH}-\mathrm{AcOEt}$ 3:1. X-Ray crystal structure ${ }^{[24]}$ determination of the resultant crystals confirmed the formation of the allyl $\alpha$-L-sorbopyranoside $\mathbf{1 4}$ as the main product (see $\mathrm{SI}$ ). The regioselective protection of diol $\mathbf{1 4}$ was next attempted. Unfortunately, the attempted reaction of 14 with TIPSCI in pyridine was not successful. Similar results were obtained when 14 was treated with $\mathrm{MOMCl}$ in pyridine. Fortunately, regioselective protection of 14 was achieved using $\mathrm{MOMCl}$ and DIPEA in dichloromethane, giving alcohol 15 in moderate yield (55\%), together with small amounts of $16(14 \%)$ and a mixture of regioisomers 15 and 17 (16\%), after chromatography. We next attempt the protection of the secondary alcohol of $\mathbf{1 5}$ as the TBS ether. However, the introduction of the TBS group failed under several conditions (TBSOTf-TEA-THF, TBSOTf-NaH-THF, TBSOTf-DBU, TBSCI-NaH-DMF). Fortunately, treatment of 15 with benzoyl chloride in pyridine gave 18 in excellent yield (93\%). The analysis of NMR data for 19 confirmed that the hydroxyl group at C-4 was protected as the MOM ether while the hydroxyl group at C-5 was protected as the benzoate ester. In addition, the mixture of 15 and 17 obtained during regioselective MOM protection of $\mathbf{1 4}$ was reacted with $\mathrm{BzCl}$ in pyridine giving both 18 and 21 that can be easily separated using chromatography. Treatment of the 3,6-O-p-methoxybenzylidene acetal 18 with $\mathrm{NaCNBH}_{3}$ and $\mathrm{TMSCl}^{[25]}$ gave the corresponding 4-O-PMB ether 19 in $59 \%$ yield.

Next, the protection of the secondary hydroxyl group of 19 was attempted. Unfortunately, protection of 19 as a TIPS ether was unsuccessful after several attempts (using TIPSCI or TIPSOTf, DMAP, DMF, $130^{\circ} \mathrm{C}$ or TIPSOTf, NaH, THF, RT), with 19 being recovered unreacted. Surprisingly, even benzylation of $\mathbf{1 9}$ failed under several conditions ( $\mathrm{NaH}$ and $\mathrm{BnBr}$ or Dudley's reagent ${ }^{[26]}$ ). Instead, removal of the allyl group, followed by installation of the protecting group at C-3 were studied. However, attempted removal of the allyl protecting group using $\mathrm{PdCl}_{2}$ at several different conditions gave the desired product in low yields (28$41 \%$ ). Fortunately, treatment of 19 with $\mathrm{OsO}_{4} / \mathrm{NalO}_{4}{ }^{[23 \mathrm{~b}]}$ followed by the simultaneous protection of both the $\mathrm{C}-3$ and $\mathrm{C}-6 \mathrm{OH}$ groups as TBS ethers gave $\mathbf{2 0}$ in good yield ( $58 \%$ over two steps). With 20 in hand, chain branching at $\mathrm{C}-2$ using the Wittig reaction was investigated. Treatment of 20 with $\mathrm{Ph}_{3} \mathrm{PCH}_{3} \mathrm{Br}$ and $t \mathrm{BuOK}$ gave the desired alkene 22 in $61 \%$ yield. Regioselective removal of the TBS group at the primary position of 22 using $10 \% \mathrm{TsOH}$ in $\mathrm{MeOH}$ gave a primary alcohol, which was oxidized using LeyGriffith conditions and gave aldehyde 23 in good yield. Again, compound 23 was reacted with $\mathrm{Ph}_{3} \mathrm{PCH}_{3} \mathrm{Br}$ and $t \mathrm{BuOK}$ to give diene 24 (Scheme 4). However, the reaction of 24 with the Grubbs $2^{\text {nd }}$ generation catalyst in toluene only gave a complex mixture at different temperatures (from $80^{\circ} \mathrm{C}$ to reflux). Fortunately, RCM of 24 in dichloromethane under microwave irradiation gave the orthogonally protected cyclopentene 25 in good yield (71\%). Removal of PMB group in $\mathbf{2 5}$ was successful using DDQ- $\mathrm{H}_{2} \mathrm{O}$ leading to $26(66 \%)$. Treatment of 26 with $\mathrm{MnO}_{2}$ gave the $\alpha, \beta$ unsaturated aldehyde $\mathbf{2 7}$ in $74 \%$ yield. Aldehyde 27 was then reacted with isopropenylmagnesium bromide to give secondary alcohol $28(72 \%)$ that was finally oxidized with $\mathrm{MnO}_{2}$ giving the orthogonally protected advanced intermediate 7 in $93 \%$ yield (Scheme 3).

Importantly, advanced intermediate 7 has potential to be used for the preparation of analogues of MDR modulators such as jatrophanes and can be also used for the preparation of biologically active cyclopentitols. In addition, intermediate 7 was screened against a panel of human cancer cell lines derived from colon (HT29, Ls174t, SW620), lung (A549) and cervical cancer (HeLa). We took advantage that 7 has a silyl ether, a feature that could increase cellular uptake and enhance anti-proliferative effects. In addition, It has also been demonstrated that no "element-specific" toxicity is associated with organosilicon compounds. ${ }^{[27]}$ Padron and co-workers have demonstrated that 
the presence of TBS ether enhance the anti-proliferative effects of tetrahydropyrans derivatives in HL60 (human promyelocytic leukemia) and MCF7 (human breast cancer) cell lines. ${ }^{[28]}$ Furthermore, trialkylsilyl campothecine derivatives such as cositecan ${ }^{[29]},{ }^{[30]}$ and DB-67 ${ }^{[31]}$ are promising compounds for cancer treatment and are currently in phase III and II clinical trials respectively.
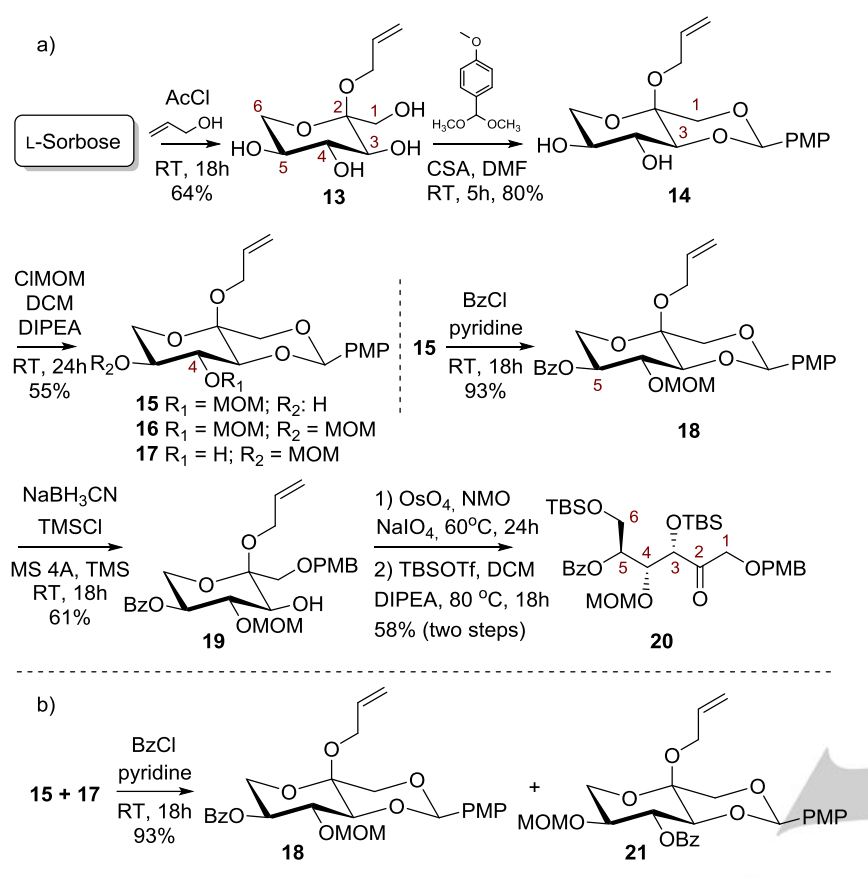

c)
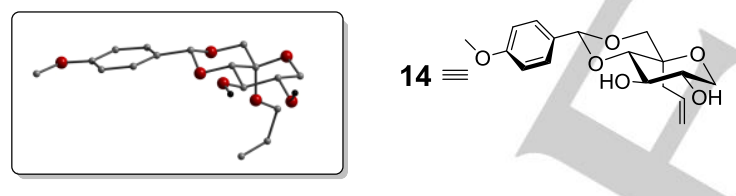

Crystal structure of 14. Colour code: Grey (C), Red (O)

Scheme 2. a) Synthesis of open-chain intermediate 20 ; b) resolution of 15-17 mixture; c) crystal structure of $\mathbf{1 4}$.

Compound 7 showed good toxicity in the XTT assay with $\mathrm{IC}_{50}$ range of 6.1-35.1 $\mu \mathrm{M}$. Compound 7 is generally less potent than widely used chemotherapeutics cisplatin or oxaliplatin while in HT29 colon cancer cell line, displayed an activity similar to cisplatin. Previous studies have demonstrated the ability of jathropane diterpenes to reduce the activity of $A B C$ proteins linked with multi-drug resistance (MDR). ${ }^{[32]}$ Compound 7 can be considered as an analogue of ring $A$ of jatrophane (figure 1). In light of that, we decided to test 7 against ABCC2 (MRP2), ABCC3 (MRP3) and ABCB1 (MDR1 or P-gp). At the concentration of 20 $\mu \mathrm{M}$, compound 7 show weakly inhibit ABCC2 (10.5 $\pm 0.25 \%)$, ABCC3 $(6.1 \pm 0.35 \%)$ and ABCB1 (7.1 $\pm 0.65 \%)$ indicating that truncated $^{[33]}$ jatrophane analogues might have potential to be developed into MDR modulators.

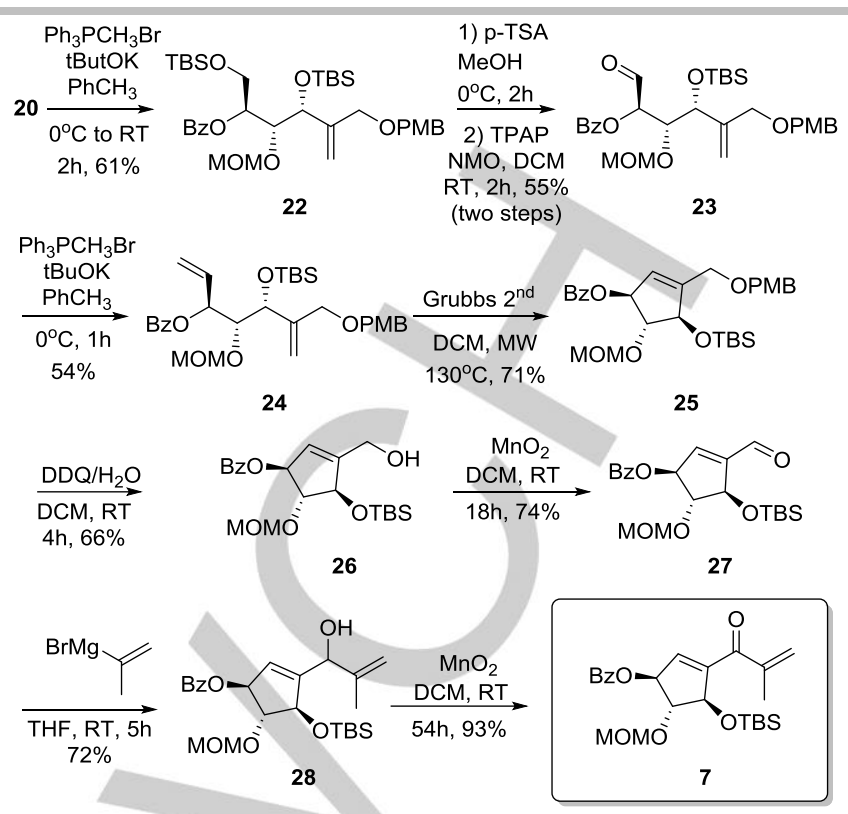

Scheme 3. Synthesis of polyhydroxylated cyclopentene 7.

In conclusions, we have developed a synthetic approach for the converstion of L-sorbose to allyl $\alpha$-L-sorbopyranoside (13). This intermediate was turned into an orthogonally protected Lsorbopyranose derivative (18). The cleavage of the allyl glycoside in 19 is compatible with different protecting group (acidic, basic and single electron oxidation sensitive). Subsequently, we also prepared the orthogonal acyclic L-sorbose derivative (20): this intermediate can be used for the preparation of more complex chiral products. We demonstrated its use in preparation of the orthogonally protected polyhydroxylated cyclopentene 7 which could have potential as an intermediate for the preparation of jatrophane analogues or for the preparation of cyclopentitols which are of particular significance because of their presence in a variety of medicinally relevant natural products. Compound, 7 was tested in a panel of human cancer cell lines (HT29, Ls174t, SW620, HeLa, A549) and displayed good cytotoxic activity. In addition, 7 weakly inhibit ABCB1 ABCC2 and ABCC3 demonstrating that it could be used as a starting point for the development of truncated jatrophane analogues as multi drug resistance (MDR) modulators.

\begin{tabular}{lccccc} 
& \multicolumn{5}{c}{$\mathrm{IC}_{\mathbf{5 0}}(\mu \mathrm{M})$} \\
\cline { 2 - 6 } & HT29 & Ls174t & SW620 & Hela & A549 \\
\hline Compound 7 & 35.1 & 11.2 & 11.9 & 6.1 & 11.2 \\
Cisplatin & 45.7 & - & - & 3.8 & 2.8 \\
Oxaliplatin & - & $1.0^{a}$ & 5.5 & - & - \\
\hline
\end{tabular}

Figure 2. Antiproliferative activity of 7: $I C_{50}$ was determinated by XTT assay. a: see ref ${ }^{[34]}$

\section{Experimental Section}

General methods and materials. All NMR spectra were recorded using a $500 \mathrm{MHz}$ spectrometer at $30^{\circ} \mathrm{C}$. Chemical shifts are reported relative to internal $\mathrm{Me}_{4} \mathrm{Si}$ in $\mathrm{CDCl}_{3}(\delta 0.0 \mathrm{ppm})$ for ${ }^{1} \mathrm{H}$ and $\mathrm{CDCl}_{3}(\delta 77.16)$ for ${ }^{13} \mathrm{C}$ 
at $30{ }^{\circ} \mathrm{C}$, unless otherwise stated. The ${ }^{13} \mathrm{C}$ signals were assigned with the aid of HSQC. The ${ }^{1} \mathrm{H}-\mathrm{NMR}$ signals were assigned with the aid of COSY. Coupling constants are reported in Hertz. High resolution mass spectra were measured using an LC Time-of-flight mass spectrometer and were measured in positive and/or negative mode as indicated. TLC were performed on aluminium sheets precoated with Silica Gel 60 (HF254, E. Merck) and spots visualized charring with vanillin solutions. Flash column chromatography was carried out using silica gel $60(0.040-0.630 \mathrm{~mm}$, E. Merck). Dichloromethane, tetrahydrofuran, $\mathrm{MeOH}$, and toluene were used as obtained from a PureSolv ${ }^{\mathrm{TM}}$ solvent purification system. Petroleum ether is the fraction with bp 40-60 ํ․

Allyl 1,3-O-(4-methoxybenzylidine)- $\alpha$-L-sorbopyranoside (14). To a stirred solution of $13(2.364 \mathrm{~g} ; 10.7 \mathrm{mmol})$ in DMF (23 $\mathrm{mL})$, camphorsulphonic acid (248 $\mathrm{mg} ; 1.07 \mathrm{mmol}$ ) and anisaldehyde dimethyl acetal $(1.82 \mathrm{~mL} ; 10.7 \mathrm{mmol})$ were added. The solution was stirred at room temperature for $5 \mathrm{~h}$. The mixture was diluted with $\mathrm{Et}_{2} \mathrm{O}(30 \mathrm{~mL})$ and washed several times with water. The solvent was evaporated and flash chromatography (EtOAc-petroleum ether 3:1) gave 14 as a white solid (2.91 g; 80\%); m.p. = $104{ }^{\circ} \mathrm{C}-109{ }^{\circ} \mathrm{C}$; [a] $]^{-} 41$ (c 0.69, $\left.\mathrm{CHCl}_{3}\right) ;{ }^{1} \mathrm{H}$ NMR $\left(\mathrm{CDCl}_{3}, 500 \mathrm{MHz}\right): \delta 7.48-7.36(\mathrm{~d}, J=8.8 \mathrm{~Hz}, 2 \mathrm{H}, \mathrm{ArCH}), 6.91-6.82(\mathrm{~d}$, $J=8.7 \mathrm{~Hz}, 2 \mathrm{H}, \operatorname{ArCH} 5.99$ (ddt, Jtrans $=16.9$, J cis $=10.5,5.3 \mathrm{~Hz}, 1 \mathrm{H}$, $\mathrm{OCH}_{2} \mathrm{CH}=\mathrm{CH}_{2}$ ), 5.51 (s, $1 \mathrm{H}, \mathrm{OCHO}$ ), 5.37 (dd, $1 \mathrm{H}, J=17.3, J_{\text {gem }}=1.7 \mathrm{~Hz}$, $\left.\mathrm{OCH}_{2} \mathrm{CH}=\mathrm{CH}_{2}\right), 5.18\left(\mathrm{dd}, 1 \mathrm{H}, J_{\text {cis }}=10.6, \mathrm{OCH}_{2} \mathrm{CH}=\mathrm{CH}_{2}\right), 4.26(\mathrm{dd}, 1 \mathrm{H}, \mathrm{J}$ $\left.=12.1,2.0 \mathrm{~Hz}, \mathrm{CH}_{2}\right), 4.18-4.11\left(\mathrm{~m}, 1 \mathrm{H}, \mathrm{OCH}_{2} \mathrm{CH}=\mathrm{CH}_{2}\right), 4.11-3.98(\mathrm{~m}$ $\left.2 \mathrm{H}, \mathrm{OCH}_{2} \mathrm{CH}=\mathrm{CH}_{2}, \mathrm{CH}\right), 3.79\left(\mathrm{~s}, 3 \mathrm{H}, J=1.4 \mathrm{~Hz}, \mathrm{OCH}_{3}\right), 3.75-3.62(\mathrm{~m}$, $\left.2 \mathrm{H}, \mathrm{CH}_{2}, \mathrm{CH}\right), 3.58-3.49\left(\mathrm{~m}, 2 \mathrm{H}, \mathrm{CH}_{2}\right), 3.44(\mathrm{dd}, 1 \mathrm{H}, \mathrm{J}=9.8,2.7 \mathrm{~Hz}, \mathrm{CH})$ ${ }^{13} \mathrm{C}$ NMR $\left(\mathrm{CDCl}_{3}, 125 \mathrm{MHz}\right): 160.4(\mathrm{ArC}), 134.4\left(\mathrm{OCH}_{2} \mathrm{CH}=\mathrm{CH}_{2}\right), 129.7$ $(\mathrm{ArC})$, 128.0, $(\mathrm{ArCH}), 116.7\left(\mathrm{OCH}_{2} \mathrm{CH}=\mathrm{CH}_{2}\right), 113.8(\mathrm{ArCH}), 102.7$ $(\mathrm{OCHO}), 92.8(\mathrm{C}-2), 82.0(\mathrm{CH}), 71.2(\mathrm{CH}), 70.7(\mathrm{CH}), 68.2\left(\mathrm{CH}_{2}\right), 63.3$ $\left(\mathrm{CH}_{2}\right), 62.0\left(\mathrm{CH}_{2}\right), 55.5\left(\mathrm{OCH}_{3}\right)$; HRMS-ESI: calcd for $\mathrm{C}_{17} \mathrm{H}_{22} \mathrm{O}_{7} \mathrm{Na}$ : 361.1263; Found: $361.1266\left(\mathrm{M}+\mathrm{Na}^{+}\right)$.

\section{Allyl 5-O-benzoyl-1,3-O-(4-methoxybenzylidine)-4-O} (methoxymethoxy)- $\alpha$-L-sorbopyranoside (18). To a stirred solution of $15(430 \mathrm{mg} ; 1.12 \mathrm{mmol})$ in pyridine $(10 \mathrm{~mL})$ at $0{ }^{\circ} \mathrm{C}, \mathrm{BzCl}(195 \mu \mathrm{L} ; 1.68$ $\mathrm{mmol}$ ) was added. The mixture was stirred at room temperature for $18 \mathrm{~h}$. TLC (petroleum ether-EtOAc, 2:1) showed a new spot with higher $\mathrm{R}_{f}$ and the absence of 15 . The solution was diluted with dichloromethane $(20 \mathrm{~mL})$, and washed with $1 \% \mathrm{HCl}(20 \mathrm{~mL})$, dried over $\mathrm{Na}_{2} \mathrm{SO}_{4}$, filtered and the solvent was removed. Flash chromatography) (cyclohexane-EtOAc, 5:1) gave 18 as a yellow oil (508 mg; $93 \%$ ); [a] $:-17.16$ (c $\left.0.85, \mathrm{CHCl}_{3}\right) ;{ }^{1} \mathrm{H}$ NMR $\left(\mathrm{CDCl}_{3}, 500 \mathrm{MHz}\right): 8.09(\mathrm{~m}, 2 \mathrm{H}, \mathrm{ArCH}), 7.60-7.55(\mathrm{~m}, 1 \mathrm{H}, \mathrm{ArCH})$, 7.47-7.43 (m, 4H, ArCH), 6.89 (d, 2H, J = = 8.8 Hz, ArCH), 6.03 (ddt, 1H, $\left.J_{\text {trans }}=17.3, J_{\text {cis }}=10.6,5.4 \mathrm{~Hz}, \mathrm{OCH}_{2} \mathrm{CH}=\mathrm{CH}_{2}\right), 5.59(\mathrm{~s}, 1 \mathrm{H}, \mathrm{OCHO}), 5.40$ (dd, $\left.1 \mathrm{H}, J_{\text {trans }}=17.2, J=1.7 \mathrm{~Hz}, \mathrm{OCH}_{2} \mathrm{CH}=\mathrm{CH}_{2}\right), 5.27-5.16(\mathrm{~m}, 2 \mathrm{H}$, $\left.\mathrm{OCH}_{2} \mathrm{CH}=\mathrm{CH}_{2}, \mathrm{H}-5\right), 4.84\left(\mathrm{~d}, 1 \mathrm{H}, J=6.8 \mathrm{~Hz}, \mathrm{OCH}_{2} \mathrm{O}\right), 4.67(\mathrm{~d}, 1 \mathrm{H}$, $\mathrm{OCH}_{2} \mathrm{O}$ ), 4.47 (dd, $\left.1 \mathrm{H}, J_{3,4}=J_{4,5}=9.4 \mathrm{~Hz}, \mathrm{H}-4\right), 4.32\left(\mathrm{~d}, 1 \mathrm{H}, J_{1,1^{\prime}}=12.1\right.$ $\mathrm{Hz}, \mathrm{H}-1$ ), 4.21 (ddt, $1 \mathrm{H}, J=12.7,5.1,1.6 \mathrm{~Hz}, \mathrm{OCH}_{2} \mathrm{CH}=\mathrm{CH}_{2}$ ), 4.08 (ddt, $1 \mathrm{H}, J=12.7,5.1,1.6 \mathrm{~Hz}, \mathrm{OCH}_{2} \mathrm{CH}=\mathrm{CH}_{2}$ ), 4.01 (dd, $1 \mathrm{H}, J_{6,6^{\prime}}=10.6, J_{6,5}=$ $6.4 \mathrm{~Hz}, \mathrm{H}-6), 3.81\left(\mathrm{~s}, 3 \mathrm{H}, \mathrm{ArOCH}_{3}\right), 3.74(\mathrm{~d}, 1 \mathrm{H}, \mathrm{H}-3), 3.68-3.61(\mathrm{~m}, 2 \mathrm{H}$, $\left.\mathrm{H}^{-1}, 6^{\prime}\right), 3.18$ (s, 3H, OCH $\left.\mathrm{OCH}_{3}\right) ;{ }^{13} \mathrm{C} \mathrm{NMR}\left(\mathrm{CDCl}_{3}, 125 \mathrm{MHz}\right): \delta 165.8$ (CO), $160.3(\mathrm{ArC}), 134.4\left(\mathrm{OCH}_{2} \mathrm{CH}=\mathrm{CH}_{2}\right), 133.5(\mathrm{ArCH}), 129.9(\mathrm{ArC})$, $129.9(\mathrm{ArCH}), 129.6(\mathrm{ArC}), 128.6(\mathrm{ArCH}), \quad 127.8(\mathrm{ArCH}), 116.8$ $\left(\mathrm{OCH}_{2} \mathrm{CH}=\mathrm{CH}_{2}\right), 113.7(\mathrm{ArCH}), 102.4(\mathrm{OCHO}), 97.3\left(\mathrm{OCH}_{2} \mathrm{O}\right), 93.0(\mathrm{C}-2)$, 82.1 (C-3), 73.0 (C-4), 71.7 (C-5), $68.1(\mathrm{C}-1), 62.3\left(\mathrm{OCH}_{2} \mathrm{CH}=\mathrm{CH}_{2}\right), 60.9$ (C-6), $55.8\left(\mathrm{OCH}_{2} \mathrm{OCH}_{3}\right), \quad 55.4\left(\mathrm{ArOCH}_{3}\right)$; HRMS-ESI: calcd for $\mathrm{C}_{26} \mathrm{H}_{30} \mathrm{O}_{9} \mathrm{Na}$ : 509.1788; Found: $509.1788\left(\mathrm{M}+\mathrm{Na}^{+}\right)$.

\section{5-O-benzoyl-3,6-di-O-(Tert-butyldimethylsilyl)-1-O-(4-}

methoxybenzyl)-4-O-(methoxymethoxy)-L-sorbose (20). To a stirred solution of 19 (657 mg; $1.34 \mathrm{mmol})$ in dioxane $(6.5 \mathrm{~mL})$ and $\mathrm{H}_{2} \mathrm{O}(0.7 \mathrm{~mL})$, $\mathrm{NMO}$ (473 mg; $4.039 \mathrm{mmol}), \mathrm{OsO}_{4}(1.419 \mathrm{~mL} ; ~ 0.134 \mathrm{mmol}, 2.5 \%$ in $t$ $\mathrm{BuOH}), \mathrm{NaIO}_{4}(1.146 \mathrm{~g} ; 5.36 \mathrm{mmol})$ and $\mathrm{H}_{2} \mathrm{O}(2.6 \mathrm{~mL})$ were added. The resulting solution was stirred at $60^{\circ} \mathrm{C}$ for $24 \mathrm{~h}$. TLC (petroleum etherEtOAc 1:1) showed a new spot with lower $\mathrm{R}_{f}$ and the absence of 19 . The mixture was diluted with dichloromethane and washed with $\mathrm{H}_{2} \mathrm{O}$. The organic layers were washed with aq satd $\mathrm{Na}_{2} \mathrm{~S}_{2} \mathrm{O}_{3}$. The organic phase was dried and the solvent was removed. The crude mixture was dissolved in DMF $(6.5 \mathrm{~mL})$, DIPEA $(1.87 \mathrm{~mL} ; 10.72 \mathrm{mmol})$ and TBSOTf $(1.229 \mathrm{~mL}$ $5.36 \mathrm{mmol}$ ) were added and the resulting solution was stirred at $80{ }^{\circ} \mathrm{C}$ for 18h. TLC (petroleum ether-EtOAc 1:1) showed a new spot with higher $\mathrm{R}_{f}$ and the absence of starting material. The solution was diluted with dichloromethane and washed with $\mathrm{H}_{2} \mathrm{O}$. The organic phase was dried and the solvent was removed. Flash chromatography (cyclohexane-EtOAc, $30: 1$ to $10: 1$ gradient elution gave 20 as a yellow oil $(525 \mathrm{mg} ; 58 \%$ over two steps); $[\alpha]_{\mathrm{D}},-19.6^{\circ}$ (c $\left.0.41, \mathrm{CHCl}_{3}\right) ;{ }^{1} \mathrm{H} \mathrm{NMR}\left(\mathrm{CDCl}_{3}, 500 \mathrm{MHz}\right): \delta$ 8.03-7.97 (m, 2H, ArCH), 7.55-7.50 (m, 1H, ArCH), $7.41(\mathrm{t}, 2 \mathrm{H}, J=7.8$ $\mathrm{Hz}, \operatorname{ArCH}), 7.09(\mathrm{~d}, 2 \mathrm{H}, J=8.6 \mathrm{~Hz}, \operatorname{ArCH}), 6.79(\mathrm{~d}, 2 \mathrm{H}, J=8.6 \mathrm{~Hz}, \mathrm{ArCH})$, 5.39 (td, $1 \mathrm{H}, J=5.8,4.3 \mathrm{~Hz}, \mathrm{H}-5), 4.75\left(\mathrm{~d}, 2 \mathrm{H}, \mathrm{J}=1.6 \mathrm{~Hz}, \mathrm{CH}_{2}\right), 4.50$ (d, $1 \mathrm{H}, \mathrm{J}=5.1 \mathrm{~Hz}, \mathrm{H}-3), 4.34-4.24\left(\mathrm{~m}, 2 \mathrm{H}, \mathrm{CH}_{2}\right), 4.22-4.13(\mathrm{~m}, 3 \mathrm{H}, \mathrm{H}-4$ and $\mathrm{CH}_{2}$ ), 3.85 (dd, $2 \mathrm{H}, J=5.9,1.4 \mathrm{~Hz}, \mathrm{H}-6$ ), 3.78 (s, 3H, ArOCH$H_{3}$ ), 3.39 (s, $\left.3 \mathrm{H}, \mathrm{OCH}_{2} \mathrm{OCH}_{3}\right), 0.90$ (s, 9H, C( $\left.\left.\mathrm{CH}_{3}\right)_{3}\right), 0.86$ (s, 9H, C(CH3) $)_{3}, 0.08$ (s, 3H, $\left.\mathrm{SiCH}_{3}\right), 0.03\left(\mathrm{~m}, 9 \mathrm{H}, 3 \mathrm{SiCH}_{3}\right) ;{ }^{13} \mathrm{C} \mathrm{NMR}\left(\mathrm{CDCl}_{3}, 125 \mathrm{MHz}\right): \delta 206.3(\mathrm{C}=\mathrm{O})$, $165.8(\mathrm{C}=\mathrm{O}), 159.4(\mathrm{ArC}), 133.2(\mathrm{ArCH}), 130.0(\mathrm{ArCH}), 129.9(\operatorname{ArC}), 129.6$ $(\mathrm{ArCH}), 129.5(\mathrm{ArC}), 128.5(\mathrm{ArCH}), 113.8(\mathrm{ArCH}), 98.2\left(\mathrm{CH}_{2}\right), 77.5(\mathrm{C}-4)$, $76.3(\mathrm{C}-3), 73.1\left(\mathrm{CH}_{2}\right), 72.9\left(\mathrm{CH}_{2}\right), 60.5(\mathrm{C}-5), 56.4\left(\mathrm{CH}_{2}\right), 55.4\left(\mathrm{ArOCH}_{3}\right)$,

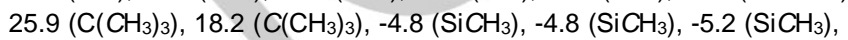
$5.4\left(\mathrm{SiCH}_{3}\right)$; HRMS-ESI: calcd for $\mathrm{C}_{35} \mathrm{H}_{56} \mathrm{O}_{9} \mathrm{Si}_{2} \mathrm{Na}$ : 699.3361; Found: $699.3354\left(\mathrm{M}+\mathrm{Na}^{+}\right)$.

\section{(1S,4R,5R)-4-(Tert-butyldimethylsilyl)oxy)-3-methacryloyl-5-} (methoxymethoxy)cyclopent-2-en-1-yl benzoate (7). To a stirred solution of $28(20.0 \mathrm{mg} ; 0.045 \mathrm{mmol})$ in dichloromethane $(1.0 \mathrm{~mL}), \mathrm{MnO}_{2}$ (39 mg; $0.45 \mathrm{mmol}$ ) was added. The resulting solution was stirred at room temperature for $48 \mathrm{~h}$. The mixture was filtered through celite with dichloromethane $(50 \mathrm{~mL})$ and the solvent was removed. The crude was redissolved in dichloromethane $(1.0 \mathrm{~mL}), \mathrm{MnO}_{2}(20 \mathrm{mg} ; 0.23 \mathrm{mmol})$ was added and the resulting mixture was stirred at room temperature for additional $6 \mathrm{~h}$. The mixture was filtered through celite with dichloromethane $(50 \mathrm{~mL})$ and the solvent was removed. Flash chromatography (EtOAccyclohexane $1: 10)$ gave 7 as a yellow oil $(18.7 \mathrm{mg} ; 93 \%) ;{ }^{1} \mathrm{H} \mathrm{NMR}\left(\mathrm{CDCl}_{3}\right.$, $500 \mathrm{MHz}): \delta 8.12-8.06(\mathrm{~m}, 2 \mathrm{H}, \mathrm{ArCH}), 7.61-7.56(\mathrm{~m}, 1 \mathrm{H}, \mathrm{ArCH}), 7.46$ $(\mathrm{t}, 2 \mathrm{H}, \mathrm{J}=7.8 \mathrm{~Hz}, \operatorname{ArCH}), 6.16\left(\mathrm{~d}, 1 \mathrm{H}, J_{1,2}=1.9 \mathrm{~Hz}, \mathrm{H}-2\right), 6.00(\mathrm{~s}, 1 \mathrm{H}$ $\left.\mathrm{C}(\mathrm{Me})=\mathrm{CH}_{2}\right), 5.90\left(\mathrm{~s}, 1 \mathrm{H}, \mathrm{C}(\mathrm{Me})=\mathrm{CH}_{2}\right), 5.71\left(\mathrm{dd}, 1 \mathrm{H}, J_{1,5}=4.4 \mathrm{~Hz}, \mathrm{H}-1\right)$ $5.02\left(\mathrm{~d}, 1 \mathrm{H}, \mathrm{J}_{4,5}=4.0 \mathrm{~Hz}, \mathrm{H}-4\right), 4.77\left(\mathrm{q}, 2 \mathrm{H}, \mathrm{J}=6.8 \mathrm{~Hz}, \mathrm{OCH}_{2} \mathrm{O}\right), 4.29$ (appt, $\left.1 \mathrm{H}, J_{1,4}=J_{1,5}=4.2 \mathrm{~Hz}, \mathrm{H}-5\right), 3.33\left(\mathrm{~s}, 3 \mathrm{H}, \mathrm{OCH}_{3}\right), 1.93(\mathrm{~s}, 3 \mathrm{H}$ $\left.\mathrm{C}(\mathrm{Me})=\mathrm{CH}_{2}\right), 0.85\left(\mathrm{~s}, 9 \mathrm{H}, \mathrm{C}\left(\mathrm{CH}_{3}\right)_{3}\right), 0.15\left(\mathrm{~s}, 3 \mathrm{H}, \mathrm{SiCH}_{3}\right), 0.07(\mathrm{~s}, 3 \mathrm{H}$, $\left.\mathrm{SiCH}_{3}\right) ;{ }^{13} \mathrm{C} \mathrm{NMR}\left(\mathrm{CDCl}_{3}, 125 \mathrm{MHz}\right)$ : $\delta 194.5(\mathrm{C}=\mathrm{O}), 166.1(\mathrm{C}=\mathrm{O}), 146.4$ $(C), 144.5(C), 133.4(\mathrm{ArCH}), 133.2(\mathrm{C}-2), 130.0(C), 129.9(\mathrm{ArCH}), 128.8$ $\left(\mathrm{C}(\mathrm{Me})=\mathrm{CH}_{2}\right), 128.6(\mathrm{ArCH}), 97.2\left(\mathrm{OCH}_{2} \mathrm{O}\right), 90.6(\mathrm{C}-5), 79.9(\mathrm{C}-1), 78.7$ $(\mathrm{C}-4), 56.1\left(\mathrm{OCH}_{3}\right), 25.8\left(\mathrm{C}\left(\mathrm{CH}_{3}\right)_{3}\right), 18.1\left(\mathrm{C}(\mathrm{Me})=\mathrm{CH}_{2}\right), 17.4\left(\mathrm{C}\left(\mathrm{CH}_{3}\right)_{3}\right)$, $4.6(\mathrm{SiCH})$, -5.0 $\left(\mathrm{SiCH}_{3}\right)$; HRMS-ESI: calcd for $\mathrm{C}_{24} \mathrm{H}_{34} \mathrm{O}_{6} \mathrm{SiNa}$ : 469.2022; Found: 469.2015

Cell Culture. A549 (non-small cell lung cancer, human), HT29 (colorectal adenocarcinoma, human), SW620 (colorectal, Dukes' type $\mathrm{C}$, human) and Ls174t (colorectal, Dukes' type B, human), HeLa (cervix adenocarcinoma, human) cells were grown in $75 \mathrm{~cm}^{2}$ culture flasks (Corning® Flask) as adherent monolayer cultures in Dulbecco's Modified Eagle Medium (DMEM) (GIBCO, ref. 41966-029). Culture mediums were supplemented with $10 \%$ heat-inactivated fetal bovine serum, and with Penicillin/Streptomycin (Gibco, 15140-122). Cultures were maintained at $37^{\circ} \mathrm{C}$ in a humidified atmosphere containing $5 \% \mathrm{CO}_{2}$ and $95 \%$ air.

Inhibition of Cell Viability Assay. Drug effects on exponentially growing tumour cells were determined using XTT assay as described previously. ${ }^{35}$ A549, HT29, SW620, Ls174t, HeLa cells were seeded at a density of 3000 cells/well in 96 -well plates and incubated for $24 \mathrm{~h}$. Thereafter, cancer cells were exposed to drugs at different concentrations during $72 \mathrm{~h}$. At $72 \mathrm{~h}, 50$ $\mu \mathrm{L}$ of XTT/ECR 1:50 solution was added and incubated for a further $4 \mathrm{~h}$ at $37^{\circ} \mathrm{C}$. .Absorbance measured at $475 \mathrm{~nm}$ was converted to percentages. UV-vis absorbance was measured at $475 \mathrm{nM}$ using a microplate reader. Experiments were performed in triplicated for each drug concentration and carried out independently at least three times. The interpolation analysis was done using dose-dependent inhibition pattern ( $\log ^{3 \mathrm{~d}}$ vs. normalized 
response \{Variable slope\}) with Prism version 5.00 software (GraphPad Software, USA).

Drug transporter inhibition assay. Cells are seeded in a 96-well culture plate typically at 20,000 cells/well and are used on days 2 or 3 postseeding. On the day of assay the test compound is prepared in assay buffer (HBSS-HEPES, pH 7.4), added to the cell plate, and pre-incubated at $37^{\circ} \mathrm{C}$ for $15 \mathrm{~min}$. Subsequently substrate is added to the plate followed by 20 -min incubation at $37^{\circ} \mathrm{C}$. The plate is then washed with cold assay buffer followed by fluorescence reading for assays with fluorogenic substrates. Cell lines: MDR1-MDCKII (Transporter: P-gp, substrate: Calcein AM, positive control Verapamil $\mathrm{IC}_{50}=29 \mu \mathrm{M}$ ); MRP2-HEK (Transporter: MRP2, substrate CDCF, positive control MK571 IC $50=14$ $\mu \mathrm{M})$; -HEK; MRP3-HEK (Transporter: MRP2, substrate CDCF, positive control MK571 IC $\mathrm{C}_{50}=12 \mu \mathrm{M}$ ).

\section{Acknowledgements ((optional))}

This work was supported by Science Foundation Ireland (grant Nos. 07/IN.1/B966 and 11/TIDA/B2047). The research leading to these results also received funding from the People Programme (Marie Curie Actions) of the European Union's Seventh Framework Programme (FP7/20072013) under grant agreement number PIEF-GA-2011-299042 and from the European Union's Seventh Framework Programme for research, technological development and demonstration under grant agreement no 600404 and from MINECO-FEDER (Bio2013-40716-R). IRB Barcelona is the recipient of a Severo Ochoa Award of Excellence from MINECO (Government of Spain).

Keywords: glycomimetics • chiral pool $\bullet$ carbohydrate $•$ orthogonal protection

[1] E. Borowski, M. M. Bontemps-Gracz, A. Piwkowska, Acta Biochim Pol 2005, 52, 609-627.

[2] H. Lage, N. Duarte, C. Coburger, A. Hilgeroth, M. J. Ferreira, Phytomedicine 2010, 17, 441-448.

[3] aG. Corea, E. Fattorusso, V. Lanzotti, O. Taglialatela-Scafati, G. Appendino, M. Ballero, P.-N. Simon, C. Dumontet, A. Di Pietro, Journal of Medicinal Chemistry 2003, 46, 3395-3402; bG. Corea, E. Fattorusso, V. Lanzotti, R. Motti, P. N. Simon, C. Dumontet, A. Di Pietro, Planta Med 2004, 70, 657-665; cG. Corea, E. Fattorusso, V. Lanzotti, R. Motti, P. N. Simon, C. Dumontet, A. Di Pietro, J Med Chem 2004, 47, 988-992; dE. Barile, M. Borriello, A. Di Pietro, A. Doreau, C. Fattorusso, E. Fattorusso, V. Lanzotti, Organic \& Biomolecular Chemistry 2008, 6, 1756-1762.

[4] L. Betancur-Galvis, J. Checa, J. A. Marco, E. Estornell, Jatrophane diterpenes from the latex of Euphorbia obtusifolia with inhibitory activity on the mammalian mitochondrial respiratory chain, Planta Med. 2003 Feb;69(2):177-8. [5] I. Mucsi, J. Molnar, J. Hohmann, D. Redei, Cytotoxicities and anti-herpes simplex virus activities of diterpenes isolated from Euphorbia species, Planta Med. 2001 Oct;67(7):672-4.

[6] R. M. Buey, I. Barasoain, E. Jackson, A. Meyer, P. Giannakakou, I. Paterson, S. Mooberry, J. M. Andreu, J. F. Diaz, Chem Biol 2005, 12, 1269 1279.

[7] A. M. Adelekan, E. A. Prozesky, A. A. Hussein, L. D. Urena, P. H. van Rooyen, D. C. Liles, J. J. Meyer, B. Rodriguez, J Nat Prod 2008, 71, 1919-1922. [8] C. Valente, M. Pedro, J. R. Ascenso, P. M. Abreu, M. S. Nascimento, M. J. Ferreira, Planta Med 2004, 70, 244-249.

[9] C. Schnabel, K. Sterz, H. Müller, J. Rehbein, M. Wiese, M. Hiersemann, The Journal of Organic Chemistry 2011, 76, 512-522.

[10] aA. Berecibar, C. Grandjean, A. Siriwardena, Chem Rev 1999, 99, 779844; bP. M. Flatt, T. Mahmud, Nat Prod Rep 2007, 24, 358-392; cV. B. Kurteva, C. A. Afonso, Chem Rev 2009, 109, 6809-6857.

[11] aB. E. Ledford, E. M. Carreira, Journal of the American Chemical Society 1995, 117, 11811-11812; bG. Wegener, V. Tschiedel, P. Schloder, O. Ando, J Exp Biol 2003, 206, 1233-1240.
[12] G. Guha, W. Lu, S. Li, X. Liang, M. F. Kulesz-Martin, T. Mahmud, A. K. Indra, G. Ganguli-Indra, PloS one 2015, 10, e0125322.

[13] A. K. Isaacs, S. Qi, R. Sarpong, J. E. Casida, Chemical Research in Toxicology 2012, 25, 1571-1573.

[14] aK. Umino, T. Furumai, N. Matsuzawa, Y. Awataguchi, Y. Ito, J Antibiot 1973, 26, 506-512; bK. Umino, N. Takeda, Y. Ito, T. Okuda, Chem Pharm Bull 1974, 22, 1233-1238.

[15] J. Choi, K. T. Lee, M. Y. Choi, J. H. Nam, H. J. Jung, S. K. Park, H. J. Park, Biol Pharm Bull 2005, 28, 1915-1918.

[16] G. Chandra, Y. W. Moon, Y. Lee, J. Y. Jang, J. Song, A. Nayak, K. Oh, V. A. Mulamoottil, P. K. Sahu, G. Kim, T.-S. Chang, M. Noh, S. K. Lee, S. Choi, L. S. Jeong, Journal of Medicinal Chemistry 2015, 58, 5108-5120.

[17] aM. Comin, amp, x, J. a, J. B. Rodriguez, Tetrahedron 2000, 56, 46394649; bF. Thorstensson, I. Kvarnström, D. Musil, I. Nilsson, B. Samuelsson, Journal of Medicinal Chemistry 2003, 46, 1165-1179; cZ. J. Xue, P. Chen, S. Y. Peng, Y. C. Li, Tetrahedron 2006, 62, 199-204; dP. Radha Krishna, R. R Kadiyala, Tetrahedron Letters 2012, 53, 744-747; eJ. D. Padwal, D. V. Filippov B. D. Narhe, S. Aertssen, R. J. Beuving, J. C. Benningshof, G. A. van der Marel, H. S. Overkleeft, M. van der Stelt, Bioorg Med Chem 2015, 23, 2650-2655

[18] D. Lo Re, F. Franco, F. Sánchez-Cantalejo, J. A. Tamayo, European Journal of Organic Chemistry 2009, 2009, 1984-1993.

[19] I. Cumpstey, S. Gehrke, S. Erfan, R. Cribiu, Carbohydr Res 2008, 343, 1675-1692.

[20] al. Izquierdo, J. A. Tamayo, M. Rodríguez, F. Franco, D. Lo Re, Tetrahedron 2008, 64, 7910-7913; bJ. A. Tamayo, F. Franco, D. Lo Re, Synlett 2010, 2010, 1323-1326; cC. O. Brien, P. V. Murphy, Journal of Carbohydrate Chemistry 2011, 30, 626-640; dC. O'Reilly, C. O'Brien, P. V. Murphy Tetrahedron Letters 2009, 50, 4427-4429; eS. Barron, P. V. Murphy, MedChemComm 2014, 5, 1150-1158.

[21] H. Kunz, H. Waldmann, in Comprehensive Organic Synthesis, Pergamon, Oxford, 1991, pp. 631-701.

[22] T. J. Boltje, C. Li, G. J. Boons, Org Lett 2010, 12, 4636-4639.

[23] aS. Chandrasekhar, C. Raji Reddy, R. Jagadeeshwar Rao, Tetrahedron 2001, 57, 3435-3438; bP. I. Kitov, D. R. Bundle, Organic Letters 2001, 3, 28352838; cH. Tsukamoto, T. Suzuki, Y. Kondo, Synlett 2007, 2007, 3131-3136. [24] aP. McArdle, P. Daly, D. Cunningham, Journal of Applied Crystallography 2002, 35, 378; bG. Sheldrick, Acta Crystallographica Section A 1990, 46, 467-473.

[25] T. Nagano, J. Pospisil, G. Chollet, S. Schulthoff, V. Hickmann, E. Moulin, J. Herrmann, R. Muller, A. Furstner, Chemistry 2009, 15, 9697-9706.

[26] aK. W. C. Poon, S. E. House, G. B. Dudley, Synlett 2005, 2005, $3142-$ 3144; bJ. Tummatorn, P. A. Albiniak, G. B. Dudley, The Journal of Organic Chemistry 2007, 72, 8962-8964.

[27] A. K. Franz, S. O. Wilson, Journal of Medicinal Chemistry 2013, 56, 388 405.

[28] aO. J. Donadel, T. Martin, V. S. Martin, J. Villar, J. M. Padron, Bioorg Med Chem Lett 2005, 15, 3536-3539; bR. Carrillo, L. G. Leon, T. Martin, V. S. Martin, J. M. Padron, Bioorg Med Chem Lett 2006, 16, 6135-6138; cR. Carrillo, L. G. Leon, T. Martin, V. S. Martin, J. M. Padron, Bioorg Med Chem Lett 2007, 17, 780-783

[29] A. Daud, N. Valkov, B. Centeno, J. Derderian, P. Sullivan, P. Munster, P. Urbas, R. C. Deconti, E. Berghorn, Z. Liu, F. Hausheer, D. Sullivan, Clin Cancer Res 2005, 11, 3009-3016.

[30] V. J. Venditto, E. E. Simanek, Mol Pharm 2010, 7, 307-349.

[31] E. Tsakalozou, E. D. Adane, Y. Liang, S. M. Arnold, M. Leggas, Cancer Chemother Pharmacol 2014, 74, 45-54.

[32] aN. A. Colabufo, F. Berardi, M. Cantore, M. Contino, C. Inglese, M. Niso R. Perrone, Journal of Medicinal Chemistry 2010, 53, 1883-1897; bP. D. W Eckford, F. J. Sharom, Chemical Reviews 2009, 109, 2989-3011.

[33] aJ.-Y. Wach, K. Gademann, Synlett 2012, 2012, 163-170; bK. Majchrzak, D. Lo Re, M. g. Gajewska, M. g. Bulkowska, A. Homa, K. Paw?owski, T. Motyl, P. V. Murphy, M. Król, PloS one 2013, 8, e76789; cD. Lo Re, Y. Zhou, M. Nobis, K. I. Anderson, P. V. Murphy, ChemBioChem 2014, 15, 1459-1464; dD. Lo Re, Y. Zhou, J. Mucha, L. F. Jones, L. Leahy, C. Santocanale, M. Krol, P. V. Murphy, Chemistry - A European Journal 2015, 21, 18109-18121; eC. Gaul, J. T. Njardarson, D. Shan, D. C. Dorn, K. D. Wu, W. P. Tong, X. Y. Huang, M. A Moore, S. J. Danishefsky, J Am Chem Soc 2004, 126, 11326-11337; fD. Shan, L. Chen, J. T. Njardarson, C. Gaul, X. Ma, S. J. Danishefsky, X.-Y. Huang, 
Proceedings of the National Academy of Sciences of the United States of America 2005, 102, 3772-3776.

[34] R. Yin, S. Gou, Y. Sun, X. Liu, Bioorg Med Chem 2012, 20, 1461-1467. 